\title{
Maximizing Organizational Structure of Sukodono Tourism Awareness Group
}

\author{
Bramantyo Tri Asmoro* \\ Government Science Department \\ Universitas Islam Raden Rahmat \\ Malang, Indonesia \\ *bramtriasmoro@gmail.com
}

\author{
Erna Resmiatini \\ Management Department \\ Universitas Islam Raden Rahmat \\ Malang, Indonesia \\ erna.resmiatini@gmail.com
}

\begin{abstract}
Tourism Group Awareness is one of the actors in developing of local tourism. It takes a strong and professional organizational management in managing a tourism object. Moreover, the nature of the tourism group awareness is a selfhelp and self-sufficient, it demands high independence as an organization. So it is not uncommon for tourism group awareness to stop operating, one of which is the Sukodono tourism group awareness, which was created to manage Coban Pandawa tourism objects. One of the main reasons for the absence of Sukodono's tourism group awareness was that the members of Sukodono's tourism group awareness did not understand their main duties and functions. As a result, there is miscommunication within the organization and most of the members become inactive. This research was conducted qualitatively with the aim of reformulating the main tasks and functions of the Sukodono Tourism Group Awareness organizational structure using job analysis approach. Data were collected by means of observation and interviews with all tourism group awareness members who occupy positions in the organization. The result of the research is the job description of each position in a simple language structure with the aim of making it easier to understand by Sukodono Tourism Group Awareness members. The redesigning of the job description is expected to improve Sukodono organizational performance in managing Coban Pandawa tourism object.
\end{abstract}

Keywords-tourism, tourism group awareness, job analysis

\section{INTRODUCTION}

Based on Law Number 10 of 2009 concerning Tourism, tourism is a variety of tourist activities and is supported by various facilities and services provided by the community, private sector and government (include local government) [1]. Apart from functioning to meet physical, spiritual and intellectual needs, tourism in general has the aim of improving people's welfare and economic growth. The development of tourism in this modern era is no longer dominated by the government, moreover, Indonesia's territory is very large and has various potentials and local wisdom. Collaboration and synergy between related parties, namely government, society and the private sector are needed in carrying out tourism development activities [2].
Tourism development is an integral part of national development for the welfare of rural communities, so the development of the tourism sector must be encouraged in various regions to create tourist attractions. Tourism development needs to be included in the Regional Development Strategic Plan, because it can also have an impact on other development sectors, such as infrastructure. One of the areas that includes tourism development in the Regional Development Strategic Plan is the Malang Regency Government, which is outlined in the Malang Regency Regional Regulation Number 1 of 2015 concerning the Regional Tourism Development Master Plan [3]. Regional Tourism Development Master Plan (RTDPM) is a formulation of planning and utilization of tourism development in the region which includes spatial aspects, tourism business, supporting factors and tourism development in a sustainable and environmentally friendly manner.

RTDMP of Malang Regency includes two elements, namely economic and socio-cultural. The economic element speaks of increasing the competitiveness of tourism and regional income. The area must be able to create a conducive situation in order to become a tourist destination that is safe and comfortable to visit. The socio-cultural element emphasizes the preservation of culture and local wisdom, preservation of nature and the environment and is expected to foster a sense of nationalism and pride in local tourism. RTDMP is very important because it becomes a guideline or guide for actors involved related to tourism development in the region. In general, RTDMP has the following objectives [3]:

- Provide the right development direction for tourism potential starting from the aspects of product, market, spatial, human resources, management and so on, so that it can grow and develop positively and sustainably for regional development and community welfare.

- Regulating the roles of relevant stakeholders both across sectors, actors and across regions in order to encourage tourism development in a synergistic and integrated manner. 
The desire of the Malang Regency Government in developing tourism in a sustainable manner was also seen with the holding of the Malang Regency Tourism Development Master Plan 2020-2025 which was held at the Malang Regency Hall on September 18, 2020 [4]. This activity aims to update the RTDMP that was made in 2015 , so that it can provide better tourism development guidelines for tourism actors, improve the quality and quantity of tourism destinations and improve the image of tourism to attract tourists to come to Malang Regency. The Focus Group Discussion activity was initiated by the Malang Regency Tourism and Culture Office and was attended by the Head of the Regional Planning and Development Agency, the ranks of the OPD Head, the Chairperson of the Special Committee of Regional Assembly, Academics, Tourism Group Awareness and Tourism Institutions.

Activities initiated by the Malang Regency Government through the Tourism and Culture Office by inviting tourism actors, one of which is the Tourism Awareness Group, should be appreciated, because tourism group awareness is one of the main actors in regional tourism development that understands the content of local wisdom in sustainable tourism development.. The number of tourism group awareness in Malang Regency is increasing, from only five tourism group awareness in 2013, to eighty-five po tourism group awareness in 2018 [5]. Tourism group awareness is a community organization engaged in tourism management in the regions [6], although tourism group awareness can obtain organizational legality in the form of a decree from the village government, in operation tourism group awareness is an independent organization that works based on the principle of self-help and member initiative. So it is to be expected that tourism group awareness will experience very tough challenges in managing tourism, various kinds of problems will bound to happened in the process.

One of the tourism group awareness that is experiencing problems is Sukodono Tourism Group Awareness, Dampit District, Malang Regency. Sukodono Tourism Group Awareness was vacuum in managing Coban Pandawa tourism object, one of the factors was that most of the members of the organization did not understand the main tasks and functions of the organizational structure that had been created [2]. Organizations that were initially dynamic did not function properly, because each part of the organizational structure did not work properly. Human resources is one of the main elements in the success and sustainability of the organization [7], so this research aims to reformulate the main tasks and functions based on the Sukodono Tourism Group Awareness organizational structure that has been made and legalized by the village government. There was no prior research that discusses the main tasks and functions of tourism awareness groups so the novelty of this research, so the novelty of this research is the document of the main tasks and functions that have been adjusted to the needs of the organization and the competence of human resources within organization.

\section{METHODS}

This study uses qualitative research, because the researcher is a key instrument and the results of the study emphasize the meaning of generalization [8]. Qualitative research aims to describe social phenomena that cannot be measured or explained by quantitative methods [9]. The stages of qualitative research carried out in this study are problem formulation, data collection, data analysis, formulation of results and provision of suggestions or recommendations. The type of research carried out is an instrumental case study, which is a type of research that focuses on understanding a phenomenon or reformulating a theoretical explanation [10]. This type of research is considered suitable because this study tries to reformulate the main tasks and functions of Sukodono Tourism Awareness Group at Sukodono Village, Dampit District, Malang Regency.

Data collection techniques used in this study were observation and interviews. The use of observation in data collection in social research is very important, because observation is a process of activities carried out by carrying out direct observations to the object of research to have a close look at the activities carried out [10]. Meanwhile, interviews are a way of collecting data directly through verbal communication to obtain information directly from the source so that researchers can find out more in-depth phenomena. The data analysis used is descriptive qualitative, that is, the data analysis technique is done by making a description of the data collected in the field.

\section{FRAMEWORKS}

Job analysis is a foundation of a series of human resources management [11]. Job analysis helps the organization achieve its goals, because the proper job analysis process will be able to determine suitable human resources in carrying out a job. Job analysis is a systematic process in collecting data to determine knowledge, skills, abilities and other characteristics that may be needed in doing a job [12]. Some of the other objectives of the job analysis process include knowing what employees will do in a job, when, where, how, for what and what qualifications are needed in carrying out a job [13]. The data obtained in more detail includes duties, responsibilities, human abilities and performance standards. Job analysis can provide a picture that should be done from a job [14].

Job analysis is basically an activity to record, study and conclude information or facts related to a systematic and orderly position. The output of the job analysis is the job description and job specifications. Job description is a document that contains the main tasks and functions of a position. While job specification is the minimum qualification required to carry out a position. The stages in job analysis include [15]:

\section{A. Job Analysis Planning}

The job analysis process is planned to determine the goals of job analysis, whether to reformulate the main tasks and 
functions, change the organizational structure or related to compensation.

\section{B. Preparation for Job Analysis}

This stage identifies existing documents related to the position or structure to be analyzed.

\section{Perform Job Analysis}

The process of collecting and compiling data.

\section{Develop Job Descriptions and Job Specifications}

Describe and determine the main tasks and functions as well as job specifications according to the data taken in the field.

\section{E. Updating the Job Description and Job Specifications}

Conduct socialization if there are changes to job descriptions and job specifications.

\section{RESULTS AND DISCUSSION}

Job analysis activities are very important activities in an organization, because the results of job analysis can be used as a guide in structuring institutional organizations, staffing and planning educational and training needs [16]. Organizational structuring means knowing what structures will be made in an organization, arrangements for the main tasks and functions of authority as well as the qualifications required in a position. In addition to being used in formal organizations, job analysis activities can also be carried out in community organizations such as the Tourism Awareness Group which has a purpose in managing tourism in the region. It takes professional management from an organization, in this case tourism group awareness, so that the management of tourism objects in the area can run well [2].

\section{A. Job Analysis Planning}

Based on the results of observations and interviews, the job analysis activities carried out aim to reformulate the main tasks and functions of Sukodono Tourism Group Awareness organizational structure that has been made. This is because most tourism group awareness members do not understand the main duties and functions of each position that has been made, so that it has an impact on organizational performance. This is as stated by the head of tourism group awareness, Mr. Juki:

"I'm confused about the function of the chairman, the important thing is to just work and try to embrace the members" (source: processed interview result)

The organizational structure of Sukodono Tourism Group Awareness was made based on deliberation and consensus between the community, community leaders and village heads, and has obtained legality from the Sukodono Village
Government and the Malang Regency Tourism and Culture Office in the form of a Decree. So that the process of job analysis is carried out based on structures that have obtained legality. The Sukodono Tourism Awareness Group Organizational Structure [17] can be seen in Table 1.

TABLE I. SUKODONO TOURISM AWARENESS GROUP ORGANIZATIONAL STRUCTURE 2018-2023

\begin{tabular}{|l|l|l|}
\hline No & \multicolumn{1}{|c|}{ Position in Organization } & \multicolumn{1}{|c|}{ Name } \\
\hline 1 & Chairman & Juki \\
\hline 2 & Vice Chairman & Hari Suryadi \\
\hline 3 & Secretary & $\begin{array}{l}\text { Purwadi } \\
\text { Herwanto }\end{array}$ \\
\hline 4 & Treasurer & $\begin{array}{l}\text { Sumarno } \\
\text { Supani }\end{array}$ \\
\hline 5 & Security and Order Section & $\begin{array}{l}\text { Sudiono } \\
\text { Sugianto }\end{array}$ \\
\hline 6 & Creation and Beauty section & $\begin{array}{l}\text { Miseri } \\
\text { Tumijan }\end{array}$ \\
\hline 7 & Cleanliness Section & $\begin{array}{l}\text { Waji } \\
\text { Satiman }\end{array}$ \\
\hline 8 & Business Development Section & $\begin{array}{l}\text { Nurhadi } \\
\text { Edik } \\
\text { Ihsan }\end{array}$ \\
\hline 9 & Public Relations Section & $\begin{array}{l}\text { Sugiono } \\
\text { Sunardianto }\end{array}$ \\
\hline 10 & Promotion and Documentation Section & $\begin{array}{l}\text { Supriono } \\
\text { Yudi }\end{array}$ \\
\hline
\end{tabular}

Source: Decree of the Head of the Tourism and Culture Office of Malang Regency.

There are 10 position in organizational structure that need to be redesign its main task and function. The process of redesign can be divided into several stages.

\section{B. Preparation for Job Analysis}

Sukodono Tourism Awareness Group does not have a main task and authority document within internal organization, that regulates the duties and authorities of each position, so this research uses the Tourism Awareness Group Guidebook document issued by the Ministry of Tourism in 2012, one of which regulates the main tasks and functions of the structure of tourism awareness group organization. Interview guidelines are also prepared to explore data related to job practices that have been regulated in the organizational structure. This document and the results of interviews with each Sukodono Tourism Awareness Group member who occupies the position according to Table 1 will be used as the basis for the reformulation of the main tasks and functions of the Sukodono Tourism Awareness Group.

\section{Implementation of Job Analysis}

The process of job analysis was carried out on all the people who occupied the structural positions in Sukodono Tourism Awareness Group, there were 10 structures and 19 people who occupied the pokdarwis organizational structure. The processed interview results can be seen in Table 2 . 
TABLE II. PROCESSED INTERVIEW RESUlTS

\begin{tabular}{|c|c|c|}
\hline No & Position & Interview Results \\
\hline 1 & Chairman & $\begin{array}{l}\text { - Do not fully understand the } \\
\text { function as chairman } \\
\text { - Lack of understanding of the } \\
\text { authority as chairman }\end{array}$ \\
\hline 2 & Vice Chairman & $\begin{array}{l}\text { - Not in line with the chairman } \\
\text { because there is no division of } \\
\text { tasks } \\
\text { - Questioning the financial } \\
\text { management that is carried out by } \\
\text { organization }\end{array}$ \\
\hline 3 & Secretary & $\begin{array}{l}\text { - Carry out correspondence, record } \\
\text { meeting results but do not have a } \\
\text { computer and the ability to } \\
\text { operate a computer }\end{array}$ \\
\hline 4 & Treasurer & $\begin{array}{l}\text { - } \quad \text { Just save money } \\
\text { - } \quad \text { Not active so don't understand the } \\
\text { main tasks and functions }\end{array}$ \\
\hline 5 & $\begin{array}{l}\text { Security and Order } \\
\text { Section }\end{array}$ & $\begin{array}{l}\text { - Not active so don't understand the } \\
\text { main tasks and functions }\end{array}$ \\
\hline 6 & $\begin{array}{l}\text { Creation and Beauty } \\
\text { section }\end{array}$ & $\begin{array}{l}\text { - Not very active, sometimes join } \\
\text { in cleaning Coban Pandawa }\end{array}$ \\
\hline 7 & Cleanliness Section & $\begin{array}{l}\text { Perform routine community } \\
\text { service at tourist sites, but rarely } \\
\text { done due to lack of equipment } \\
\text { and other members' activities }\end{array}$ \\
\hline 8 & $\begin{array}{l}\text { Business Development } \\
\text { Section }\end{array}$ & $\begin{array}{l}\text { - Provide improvements and } \\
\text { suggestions about what is missing } \\
\text { in the organization } \\
\text { - Doing community service }\end{array}$ \\
\hline 9 & Relations & $\begin{array}{l}\text { - The task that is understood is } \\
\text { simply to gather organization } \\
\text { members during the meeting }\end{array}$ \\
\hline 10 & $\begin{array}{l}\text { Promotion and } \\
\text { Documentation Section }\end{array}$ & $\begin{array}{l}\text { - Documenting and uploading it on } \\
\text { social media but rarely done due } \\
\text { to internet quota limitations }\end{array}$ \\
\hline
\end{tabular}

From the results of the interview processed in Table 2, it can be concluded that all the people who occupy the organizational structure do not understand the main tasks and functions that should be carried out, the lines of coordination and authority are also unclear, causing miscommunication between the pokdarwis chairman and several members. As a result, some pokdarwis members became inactive in the organization due to unclear coordination within the organization.

\section{Job Description Development}

Based on the identification of problems obtained after conducting observations and the interview process, a basic document is needed, namely a document that regulates the main tasks and functions of the tourism awareness group organizational structure. One of the reasons for the nonfunctioning of the organization and the absence of some tourism awareness group members was the unclear main duties and functions carried out by the members. So that the document is expected to be a guide for the Sukodono pokdarwis organization in carrying out the organization's wheels in accordance with their respective duties and authorities. The document can be seen in Table 3 .

TABLE III. JOB DESCRIPTION OF SUKODONO TOURISM AWARENESS GROUP

\begin{tabular}{|c|c|c|}
\hline No & Position & Main Task and Function \\
\hline 1 & Chairman & $\begin{array}{l}\text { Function: } \\
\text { Leading and directing members of Sukodono } \\
\text { Tourims Awareness Group in managing Coban } \\
\text { Pandawa tourism objects } \\
\text { Main tasks: } \\
\text { - Provide direction to members in carrying } \\
\text { out the main duties and functions of each } \\
\text { position } \\
\text { - Coordinating activities } \\
\text { - Sign outgoing letters } \\
\text { - Coordinate with the village head regarding } \\
\text { Coban Pandawa tourism object } \\
\end{array}$ \\
\hline 2 & Vice Chairman & $\begin{array}{l}\text { Function: } \\
\text { Assisting the duties of the Chairman of } \\
\text { Sukodono Tourism Awareness Group } \\
\text { Main tasks: } \\
\text { - Provide input to the Chair in developing } \\
\text { Coban Pandawa tourism object } \\
\text { - Representing the chairman in activities if } \\
\text { the chairman is absent }\end{array}$ \\
\hline 3 & Secretary & $\begin{array}{l}\text { Function: } \\
\text { Carry out administrative functions } \\
\text { Main tasks: } \\
\text { - Prepare materials for group meeting } \\
\text { - Compile reports from members for activity } \\
\text { reports } \\
\text { - Record the results of routine meetings }\end{array}$ \\
\hline 4 & Treasurer & $\begin{array}{l}\text { Function: } \\
\text { Managing Sukodono pokdarwis finances } \\
\text { Main tasks: } \\
\text { - Managing income and expenses of } \\
\text { organization } \\
\text { - Make financial reports }\end{array}$ \\
\hline 5 & $\begin{array}{l}\text { Security and } \\
\text { Order Section }\end{array}$ & $\begin{array}{l}\text { Function: } \\
\text { Maintain security and order around the Coban } \\
\text { Pandawa location } \\
\text { Main tasks: } \\
\text { - Appealing and inviting members, residents } \\
\text { and tourists to always be safe and orderly } \\
\text { around the Coban Pandawa location } \\
\text { - Ensure problems are resolved properly, if } \\
\text { there are problems with security and order }\end{array}$ \\
\hline 6 & $\begin{array}{l}\text { Creation and } \\
\text { Beauty section }\end{array}$ & $\begin{array}{l}\text { Function: } \\
\text { Exploring and developing the potential for } \\
\text { tourism resources, as well as local uniqueness } \\
\text { as an attraction and an element of local } \\
\text { memories } \\
\text { Main tasks: } \\
\text { - Formulate a tourism resource development } \\
\text { program that raises the uniqueness / } \\
\text { uniqueness of the Sukodono area } \\
\text { - Ensure members, residents, and tourists } \\
\text { always maintain the beauty around the } \\
\text { Coban Pandawa location and do not } \\
\text { damage anything around the tourist site }\end{array}$ \\
\hline
\end{tabular}


TABLE III. Cont.

\begin{tabular}{|l|l|l|}
\hline No & \multicolumn{1}{|c|}{ Position } & \multicolumn{1}{|c|}{ Main Task and Function } \\
\hline 7 & $\begin{array}{l}\text { Cleanliness } \\
\text { Section }\end{array}$ & $\begin{array}{l}\text { Function: } \\
\text { Ensuring cleanliness around the Coban } \\
\text { Pandawa location is always maintained } \\
\text { Main tasks: } \\
\text { - Organizing cleaning activities } \\
\text { - Organizing and organizing reforestation }\end{array}$ \\
\hline 8 & $\begin{array}{l}\text { Business } \\
\text { Development }\end{array}$ & $\begin{array}{l}\text { Function: } \\
\text { Developing residents' efforts in relation to } \\
\text { developing Coban Pandawa tourism } \\
\text { Main tasks: } \\
\text { - Develop local business units that support } \\
\text { Coban Pandawa tourism object } \\
\text { - Integrating local economic potential with } \\
\text { tourism objects }\end{array}$ \\
\hline 9 & $\begin{array}{l}\text { Public Relations } \\
\text { Section }\end{array}$ & $\begin{array}{l}\text { Function: } \\
\text { Partnership development with external parties } \\
\text { Main tasks: } \\
\text { - Develop partnerships for tourism training } \\
\text { activities } \\
\text { Become a communicator in Coban } \\
\text { Pandawa tourism }\end{array}$ \\
\hline 10 & $\begin{array}{l}\text { Promotion and } \\
\text { Documentation } \\
\text { Section }\end{array}$ & $\begin{array}{l}\text { Function: } \\
\text { Promote Coban Pandawa tourism object } \\
\text { Main tasks: } \\
\text { - Developing information channels for } \\
\text { Coban Pandawa publications } \\
\text { Creating content to promote Coban } \\
\text { Pandawa tourist attraction and the local } \\
\text { uniqueness contained in it }\end{array}$ \\
\hline
\end{tabular}

Table 3 contains the job descriptions of each position in the Sukodono Tourism Awareness Group organizational structure, the job descriptions are simply reformulated due to the factor of the low level of education of tourism awareness group members, so it is hoped that it can be easily understood and implemented by members of Sukodono Tourism Awareness Group.

\section{CONCLUSION}

The main tasks and functions of tourism awareness group organizational structure have basically been regulated in the Tourism Awareness Group guidelines issued by the Ministry of Tourism, but due to the low level of education of Sukodono Tourism Awareness Group's members, the explanation in the guidebook is difficult to understand when socialization is carried out. So this research aims to reformulate the job description of the Sukodono Tourism Awareness Group organizational structure in a very simple way with the aim of making it easy to understand. The Sukodono Village Government also needs to provide regular assistance, so that Sukodono Tourism Awareness Group can continue to run dynamically in developing Coban Pandawa tourism objects.

\section{ACKNOWLEDGMENT}

The author wants to thank related parties such as Ministry of Research and Technology / National Research and Innovation Board as a funder in the Beginner Lecturer Research grant program, the Institute for Research and Community Service Universitas Islam Raden Rahmat as a facilitator in conducting research, Sukodono Village Government and Sukodono Tourism Awareness Group.

\section{REFERENCES}

[1] Undang-Undang Nomor 10 Tahun 2009 tentang Kepariwisataan. Indonesia, 2009.

[2] B.T. Asmoro, M. Anwartinna, and S. Handayani, "Tourism Awareness Groups (Pokdarwis) Institutional Capacity Development In Managing Coban Pandawa Tourist Attraction," Pros. ICOGISS 2019, pp. 146-156, 2019.

[3] Peraturan Daerah Kabupaten Malang Nomor 1 Tahun 2015 tentang Rencana Induk Pembangunan Pariwisata Daerah. Indonesia, 2015.

[4] "Kembangkan Potensi Kepariwisataan, PAD Diharapkan Meningkat," 2020. [Online]. Retrieved from: http://www.malangkab.go.id/mlg/default/page?title=malangkab-bupatibuka-fgd-pembangunan-kepariwisataan

[5] B.T. Asmoro and M.M. Da'awi, "Revitalisasi Kelompok Sadar Wisata (Pokdarwis) Desa Sukodono, Kecamatan Dampit, Kabupaten Malang Dalam Pengelolaan Obyek Wisata Coban Pandawa," JPM (Jurnal Pemberdaya. Masyarakat), vol. 5, no. 1, pp. 373-379, 2020.

[6] K. Pariwisata and E. Kreatif, "Pedoman kelompok sadar wisata," Jakarta: Kemenpar \& Ekraf, 2012.

[7] B.T. Asmoro and E. Resmiatini, "Penguatan Tugas Pokok dan Fungsi Pemerintah Desa dengan Pendekatan Analisis Jabatan (Studi Kasus Desa Palaan, Kecamatan Ngajum, Kabupaten Malang)," J. Ilm. Manaj. Publik dan Kebijak. Sos., vol. 4, no. 2, pp. 85-99, 2020.

[8] D.R. Sugiyono, Metodologi Penelitian Pendidikan. Bandung: Alfabeta, 2009.

[9] L.J. Moleong, Metodologi Penelitian Kualitatif. Bandung: PT. Remaja Rosdakarya, 2002.

[10] I. Nurdin and S. Hartati, Metodologi Penelitian Sosial. Surabaya: Media Sahabat Cendekia, 2019.

[11] J.E. Pynes, Human Resources Mangement for Public and Non Profit Organization, A Strategic Approach, Third. San Fransisco: A Willey Imprint, 2009.

[12] M. Zaenuri, Manajemen Sumber Daya Manusia di Pemerintahan. Yogyakarta: LP3M, 2015

[13] R.A. Noe, A.W. Noe, and J.A. Bachhuber, "An investigation of the correlates of career motivation," J. Vocat. Behav., vol. 37, no. 3, pp. 340-356, 1990.

[14] N. Saif, M.S. Khan, K. Rehman, S.U. Rehman, Z.U. Rehman, T. Nawa, and M. Naqeeb, "Competency based Job Analysis," Int. J. Acad. Res. Accounting, Financ. Manag. Sci., vol. 3, no. 1, pp. 105-111, 2013.

[15] H. Sedarmayanti, Manajemen Sumber Daya Manusia; Reformasi Birokrasi dan Manajemen Pegawai Negeri Sipil. Reflika Aditama, 2018.

[16] W. Syafri and A. Alwi, Manajemen Sumber Daya Manusia Dalam Organisasi Publik. IPDN PRESS, 2014.

[17] Surat Keputusan Kepala Dinas Pariwisata dan Kebudayaan Kabupaten Malang Nomor 556/178/KEP/35.07.108/2018 tentang Pengukuhan Kelompok Sadar Wisata "Sukodono" Desa Sukodono Kecamatan Dampit Kabupaten Malang Masa Bakti 2018-2023. Indonesia, 2018. 